\begin{tabular}{|c|c|c|c|c|}
\hline & \multicolumn{2}{|c|}{ Change in CDAI } & \multicolumn{2}{|c|}{ Achievement of LDA } \\
\hline & $\begin{array}{l}\text { Unadjusted } \\
\text { Mean (SD) }\end{array}$ & $\begin{array}{c}\text { Adjusted } \\
\beta(95 \% \mathrm{Cl})^{*}\end{array}$ & $\begin{array}{l}\text { Unadjusted } \\
\text { Response } \\
\text { Rate, n (\%) }\end{array}$ & $\begin{array}{c}\text { Adjusted } \\
\text { OR }(95 \% \text { CI)* }\end{array}$ \\
\hline $\begin{array}{l}\text { TCZ mono } \\
(n=283)\end{array}$ & $-9.7(14.6)$ & - & $82(29)$ & - \\
\hline $\begin{array}{l}\text { TNFi + MTX } \\
\leq 10 \mathrm{mg} \\
(\mathrm{n}=108)\end{array}$ & $-7.8(13.6)$ & $\begin{array}{c}-0.15 \\
(-2.92 \text { to } \\
2.62)\end{array}$ & $33(31)$ & $\begin{array}{c}1.22 \\
(0.71 \text { to } 2.10)\end{array}$ \\
\hline $\begin{array}{l}\text { TCZ mono } \\
(n=300)\end{array}$ & $-9.6(14.5)$ & - & $88(29)$ & - \\
\hline $\begin{array}{l}\text { TNFi }+M T X \\
>10 \text { to } \leq 15 \mathrm{mg} \\
(n=186)\end{array}$ & $-9.0(14.2)$ & $\begin{array}{c}-0.3 \\
(-2.83 \text { to } \\
2.22)\end{array}$ & $70(38)$ & $\begin{array}{c}0.94 \\
(0.60 \text { to } 1.48)\end{array}$ \\
\hline $\begin{array}{l}\text { TCZ mono } \\
(n=292)\end{array}$ & $-9.6(14.7)$ & - & $85(29)$ & - \\
\hline $\begin{array}{l}\mathrm{TNFi}+\mathrm{MTX} \\
>15 \text { to } \leq 20 \mathrm{mg} \\
(n=273)\end{array}$ & $-6.9(12.8)$ & $\begin{array}{c}-1.65 \\
(-3.84 \text { to } \\
0.54)\end{array}$ & $73(27)$ & $\begin{array}{c}1.4 \\
\text { (0.89 to } 2.18)\end{array}$ \\
\hline $\begin{array}{l}\text { TCZ mono } \\
(\mathrm{n}=285)\end{array}$ & $-9.7(14.7)$ & - & $85(30)$ & - \\
\hline $\begin{array}{l}\text { TNFi + MTX } \\
>20 \mathrm{mg} \\
(n=107)\end{array}$ & $-8.4(15.0)$ & $\begin{array}{c}-1.43 \\
(-5.12 \text { to } \\
2.25)\end{array}$ & $32(30)$ & $\begin{array}{c}1.26 \\
(0.70 \text { to } 2.25)\end{array}$ \\
\hline \multicolumn{5}{|c|}{$\begin{array}{l}\text { CDAI, Clinical Disease Activity Index; LDA, low disease activity; MTX, methotrexate; } \\
\text { OR, odds ratio; TCZ, tocilizumab; TNFi, tumor necrosis factor inhibitor. } \\
\text { "TCZ compared with TNFi + MTX. Adjusted for sex, age, race (white vs nonwhite), } \\
\text { disabled, retired, baseline CDAI, baseline modified Health Assessment } \\
\text { Questionnaire, baseline patient pain scores, baseline prednisone use/dose, } \\
\text { baseline body mass index, prior biologic use, prior TNFi use and American College } \\
\text { of Rheumatology functional class. }\end{array}$} \\
\hline
\end{tabular}

Employee of: Genentech, Inc, G. Persuitte Employee of: Corrona, LLC, J. Kremer Shareholder of: Corrona, LLC, Consultant for: AbbVie; Amgen; Bristol-Meyers Squibb; Genentec, Inc; GlaxoSmithKline; Lilly; Pfizer; Regeron; Sanofi, Employee of: Corrona, LLC

DOI: 10.1136/annrheumdis-2017-eular.3295

\section{AB0408 COMPARATIVE EFFECTIVENESS OF ABATACEPT VERSUS TNFI IN PATIENTS WITH RHEUMATOID ARTHRITIS WHO ARE CCP+ IN THE UNITED STATES CORRONA REGISTRY}

L. Harrold $^{1}$, H. Litman ${ }^{2}$, S. Connolly ${ }^{3}$, E. Alemao ${ }^{3}$, K. Price ${ }^{3}$, S. Kelly ${ }^{3}$, S. Rebello ${ }^{2}$, W. Hua ${ }^{2}$, J. Kremer ${ }^{4}{ }^{1}$ University of Massachusetts, Worcester; ${ }^{2}$ Corrona, LLC, Southborough; ${ }^{3}$ Bristol-Myers Squibb, Princeton; ${ }^{4}$ Albany Medical College and The Center for Rheumatology, Albany, United States

Background: Anti-cyclic citrullinated peptide positivity $(\mathrm{CCP}+)$ is associated with a better response to abatacept (ABA) than anti-CCP negativity in patients (pts) with RA ${ }^{1,2}$; however, there are no head-to-head or comparative effectiveness research studies available evaluating responses to biologics in CCP+ pts in a real-world setting.

Objectives: To compare the effectiveness of ABA vs a TNF inhibitor (TNFi) in pts with RA who are CCP+.

Methods: We identified adult pts with RA from a large observational US cohort (1 Dec 2005-31 Aug 2016) who initiated ABA or a TNFi and who were CCP+ $(\geq 20$ $\mathrm{U} / \mathrm{mL}$ ) at or prior to initiation. Both groups had to have no prior exposure to other non-TNFi biologics or targeted synthetic DMARDs. TNFi initiators were excluded if they had prior use of ABA. Using propensity score matching (1:1) stratified by prior TNFi use $(0,1$ and $2+)$, effectiveness at 6 months after initiation was evaluated. Mean change in CDAl over 6 months following initiation was the primary outcome, and secondary outcomes were: achievement of remission (CDAl $\leq 2.8$ ), modified (m)ACR20, 50 and 70 responses and achievement of LDA/remission (CDAl $\leq 10$ ) in those with moderate/high disease activity at initiation. A subset analysis was performed to consider separately pts who were biologic naïve and those who were biologic experienced at initiation.
Results: The 330 pairs of propensity score-matched ABA and TNFi initiators had no substantial differences in baseline characteristics. Both treatment groups had similar mean change in CDAl at 6 months as well as achievement of LDA, remission and mACR20/50/70 responses (Table). Among the 97 matched biologic-naïve pairs, there was no significant difference in change in CDAl for ABA initiators vs TNFi initiators $(p=0.19)$. However, in the 233 matched biologicexperienced pairs, those initiating $A B A$ had a greater improvement in mean change in CDAI ( $p=0.033)$ and were more likely to achieve an mACR50 response $(p=0.014)$.

Conclusions: Pts with RA who were CCP+ and received either ABA or TNFi had a substantial improvement in clinical disease activity. In the overall propensity score-matched sample, similar outcomes were observed for both treatment groups. However, analysis of the biologic-experienced cohort found that ABA initiators had a greater improvement in disease activity than TNFi initiators.

References:

[1] Sokolove J, et al. Ann Rheum Dis 2016:75:709-14.

[2] Harrold LR, et al. Ann Rheum Dis 2016;75(Suppl 2):505-6.

Disclosure of Interest: L. Harrold Shareholder of: Corrona, LLC, Grant/research support from: Pfizer, Consultant for: Roche, Employee of: Corrona, LLC, H. Litman Employee of: Corrona, LLC, S. Connolly Shareholder of: Bristol-Myers Squibb, Employee of: Bristol-Myers Squibb, E. Alemao Shareholder of: Bristol-Myers Squibb, Employee of: Bristol-Myers Squibb, K. Price Employee of: Bristol-Myers Squibb, S. Kelly Shareholder of: Bristol-Myers Squibb, Employee of: Bristol-Myers Squibb, S. Rebello Employee of: Corrona, LLC, W. Hua Employee of: Corrona, LLC, J. Kremer Shareholder of: Corrona, LLC, Grant/research support from: AbbVie, Genentech, Lilly, Novartis, Pfizer, Consultant for: AbbVie, Amgen, BristolMyers Squibb, Genentech, GSK, Lilly, Medlmmune, Pfizer, Sanofi, Employee of: Corrona, LLC

DOI: 10.1136/annrheumdis-2017-eular.1643

\section{AB0409 CORTICOSTEROID-SPARING IN PATIENTS WITH RHEUMATOID ARTHRITIS ON TOCILIZUMAB: FIRST EXPERIENCE OF BAB -EL- OUED HOSPITAL}

M.A. Ifticene, H. Hafirassou, R. Benaziez, F. Mechid, F. Hanni, C. Dahou Makhloufi. Hospital, algiers, Algeria

Background: Tocilizumab (TCZ) is a monoclonal antibody directed against the IL-6 receptors. This treatment (TRT) allows for the cortisone weaning in preventing of its complications.

Objectives: The goal of this study is to evaluate the corticosteroid sparing in patients with RA treated with TCZ.

Methods: Prospective, descriptive study of patients hospitalized between 2012 and 2016, the diagnosis was made according to the ACR 1987 ACR/EULAR 2010 criteria. Included, are the patients treated with TCZ for at least 3 months associated with corticosteroids.

We have studied the following: the epidemiology, the associated DMARDs, the average DAS28VS, the average dosage of prednisone-equivalent and the percentage of patients with decreased or interrupted corticosteroids at M0, M3, M6 and M12.

Results: 26 patients (sex ratio: 0.7 ) treated with $\mathrm{TCZ}$ and corticosteroids, average age is 43.4 years (range 30-62). Average duration of the development of RA: $9.1 \pm 6.4$ years. DMARDs was associated in 15 patient.

At baseline, $46.2 \%$ of patients were on $10 \mathrm{mg} /$ day of cortisone, the average dose of prednisone-equivalent was at $7.7 \pm 3.6 \mathrm{mg}$ at $\mathrm{M} 0,5.3 \pm 3.2 \mathrm{mg}$ at M3, $4.6 \pm 2.3 \mathrm{mg}$ at $\mathrm{M} 6,2.6 \pm 2.6 \mathrm{mg}$ at $\mathrm{M} 12$ with a statistically significant difference $(\mathrm{p}=0.000003)$. The average DASVS28 activity index was $5.6 \pm 0.9$ at M0, $3.5 \pm 1.3$ at M3, $3.04 \pm 1.2$ at M6 and $2.6 \pm \mathrm{M} 6$ at M12 with a statistically significant difference $(\mathrm{p}<0.000001)$. Corticosteroid treatment was stopped in 12 patients after 1 year of treatment.

Conclusions: Through this study we note that the TRT using TCZ has enabled a significant reduction in the dose of corticosteroids. Stopping prednisone was possible in $50 \%$ of patients after 1 year of biotherapy.

Disclosure of Interest: None declared

DOI: 10.1136/annrheumdis-2017-eular.3965

$\underline{\text { Abstract AB0408 - Table } 1}$

\begin{tabular}{|c|c|c|c|c|c|c|c|c|c|}
\hline & \multicolumn{3}{|c|}{ Total population } & \multicolumn{3}{|c|}{ Biologic naive } & \multicolumn{3}{|c|}{ Biologic experienced } \\
\hline & $\begin{array}{c}\mathrm{CCP}+ \\
\text { abatacept initiators } \mathrm{n}=330 \\
\mathrm{n}=330\end{array}$ & $\begin{array}{c}\text { CCP+ } \\
\text { TNFi initiators } \\
\mathrm{n}=330\end{array}$ & & $\begin{array}{c}\mathrm{CCP}+ \\
\text { abatacept initiators } \\
\mathrm{n}=97\end{array}$ & $\begin{array}{c}\mathrm{CCP}+ \\
\text { TNFi initiators } \\
\mathrm{n}=97\end{array}$ & & $\begin{array}{c}\mathrm{CCP}+ \\
\text { abatacept initiators } \\
\mathrm{n}=233\end{array}$ & $\begin{array}{c}\text { CCP+ } \\
\text { TNFi initiators } \\
\mathrm{n}=233\end{array}$ & \\
\hline Primary outcome: & Mean ( \pm SE) & Mean $( \pm$ SE) & $p$ value* & Mean $( \pm$ SE) & Mean $( \pm$ SE) & $p$ value* & Mean $( \pm$ SE) & Mean $( \pm$ SE) & $p$ value* \\
\hline Change in CDAl & $-9.9( \pm 0.8)$ & $-8.5( \pm 0.8)$ & 0.24 & $-9.8( \pm 1.4)$ & $-12.3( \pm 1.4)$ & 0.19 & $-9.9( \pm 1.0)$ & $-7.0( \pm 1.0)$ & 0.033 \\
\hline Secondary outcomes: & Response rate (\%) & Response rate (\%) & $p$ value $^{\dagger}$ & Response rate (\%) & Response rate (\%) & $p$ value $^{\dagger}$ & Response rate (\%) & Response rate (\%) & $p$ value $^{\dagger}$ \\
\hline LDA & 41.3 & 39.7 & 0.69 & 50.0 & 57.0 & 0.36 & 37.6 & 32.1 & 0.26 \\
\hline Remission & 15.5 & 14.8 & 0.83 & 19.6 & 21.6 & 0.72 & 13.7 & 12.0 & 0.58 \\
\hline mACR20 & 36.4 & 36.4 & $>0.99$ & 40.2 & 45.4 & 0.47 & 34.8 & 32.6 & 0.62 \\
\hline mACR50 & 24.8 & 21.5 & 0.31 & 26.8737 .1 & 0.12 & 24.0 & 15.0 & 0.014 & \\
\hline mACR70 & 13.6 & 10.6 & 0.23 & 17.5 & 19.6 & 0.71 & 12.0 & 6.9 & 0.057 \\
\hline
\end{tabular}

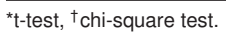

